either a paternalistic analysis of camp life or an emancipatory critique of the geopolitical conditions of exile. The contemporary problem of the refugee can be understood only if we also examine those stakeholders who have the most invested in the maintenance of refugees and refugee camps-that is, the refugee expert. In much the same way that we can today use colonial ethnography to shed light on the logic and operations of European imperial power in the past, The Ideal Refugees sheds much light on the contemporary discourse of refugee expertise and its articulation within the logics and operations of post-imperial power in the present.

Jacob Mundy is an assistant professor of peace and conflict studies at Colgate University, where he also contributes to African and Middle Eastern studies. His monograph Imaginative Geographies of Algerian Violence: Conflict Science, Conflict Management, Antipolitics will be published by Stanford University Press later this year. The author may be contacted at jmundy@colgate.edu.

\title{
Belonging in Oceania: Movement, Place-making and Multiple Identifications. Vol. 3 of Pacific Perspectives: Studies of the European Society for Oceanists
}

\author{
$\sim$ \\ Edited by Elfriede Hermann, Wolfgang Kempf, and Toon van Meijl \\ New York: Berghahn, 2014, pp. 232
}

$\mathrm{T}$ his absorbing collection of essays focuses on how immigrants make efforts to define who they are, or where and to whom they belong, through plural claims of relationships to both home and host societies. As such, it is part of the "mobility turn" in recent social theory according to which any presumed or intrinsic relationship between moral order and identity, on the one hand, and place or territory, on the other is called into question and thus shifts our attention to such phenomena as airports, travel, vehicles, virtual communities, diasporas, and so forth. ${ }^{1}$

Set in the insular Pacific, the book begins with an introductory chapter by its three editors that sets out a useful (but then largely ignored) theoretical framework. It presents a concept of moral belonging that is dispersed and diluted by global forces and transnational movement but is then reasserted through ties to "place," ties that are made primarily, although not exclusively, through claims to land tenure back home, church-related activities, as well as participation in festivals and other recreational activities.

Each chapter is a case study of immigrant experience in a different part of the region. Australian Aborigines and Papua New Guineans are included, but at least half of the book is taken up with Polynesians living in urban New Zealand, such as Nieuans, Cook Islanders, as well as of course Maori people.

Apart from Rollason's fascinating case study from Papua New Guinea that discusses shifting concepts of place that arose after a big colonial development initiative ended, several themes preoccupy the volume.
Perhaps the first one is spatial but also moral displacement and disconnection and the consequent longing and nostalgia for, or perhaps one could simply call it alienation from, the "paradise" where diaspora people view themselves as authentically belonging. This ongoing experience of loss/attachment appears in Garond's account of descendants of mainland Australian Aborigines living on Palm Island, where their ancestors were "removed" to prison-like reserves by the state. It is discussed in Thode-Arora's chapter on Nieu Islanders who left their small island state to find work in Auckland. It is prominent in Brandt's chapter on urban Maori. Lastly, it appears in Kempf and Hermann's peculiar epilogue, which does not really address the important issues the volume raises in any comprehensive way but rather focuses on the projected effects of climate change and rising sea levels on the future of place and society in the island state of Kiribati.

The second theme, which is the book's main one, is how diaspora peoples try to construct themselves in networks and in terms of "multiple belonging" both to the places they have lost and the places where they have come to reside. One important modality of this project is, as I say, through land claims. A couple of startling images caught my attention in this regard. Nieuan healers use ingredients imported from their island, but pastors and church elders possess power (mana) not from the land, as they would at home, but from the offices they occupy. Land, say urban Cook Islanders in New Zealand, is "the mother of identity," but they have no moral connection with, and gain no agency from, land in the diaspora. Meanwhile, absentee landowners, who make
(C) Author(s), 2015. This open-access work is licensed under a Creative Commons Attribution-NonCommercial 4.0 International licence.
Cette oeuvre en libre accès fait l'object d'une licence Creative Commons Attribution-NonCommercial 4.0 International. 
contested claims to ancestral property in the Cook Islands, have become something of a problem. Half-finished houses are a common sight there but so are well-kept, yet empty plots of land that are planted with ornamental flowers or with short-term crops, like tomatoes. In a similar way, perhaps, urban Maori youth try to reconnect with their sacred status as "custodians of the land" by burying the placenta of newborns not necessarily on their lineage lands but beneath urban meeting halls (marae) where they otherwise lack ancestral ties.

Ironically, it is the churches, whose missionary activities sought so hard to erase or at least reduce local allegiances and local particularisms, or to put it more bluntly, local culture, now offer a very important institutional framework for building transnational moral solidarity within and among Pacific diasporas. They provide settings for sustaining local, place-based identities. In Auckland, Nieuans sit in rival village groups in church and sing their own community-based hymns. Fer and Malogne-Fer report that Pacific Islanders create "new localities" (148) for themselves and new island identities when they assemble in churches for rites of passage, to celebrate the independence of their home states and gather in various voluntary associations, such as women's weaving, or other self-help groups.

At the same time as islanders try to maintain transnational ethnic identities, acculturation processes go on. Senior Cook Islanders in Auckland want to retire back home where not everything is a commodity and kinship values (aroha) prevail. Yet processes occur that raise questions about the moral status of second- and third-generation youth. Youth lose vernacular language fluency, possess no first-hand experience with home, and feel stronger loyalties to school and neighbourhood rather than to a vague memory of a place and time never experienced. Like their elders, such young people nevertheless retain attachment either to specific villages or tribal ethnicities back home. We see some of this sort of allegiance in Dürr's chapter describing reactions of Maori high school students to a monthlong visit to Mexico. Its fragility, however, is also evident in efforts some churches make to recruit Polynesian young people. Evangelical movements in a Polynesian idiom have arisen seeking to promote a "new birth" of pan-Pacific identity (156).

I mentioned the epilogue's focus on the pending tragedy of rising sea levels and climate change in the Pacific above and want to return to an important point that Kempf and Hermann make in their discussion. How, they ask, can we begin to think about the migrations of climate refugees that will inevitably result? How can we begin to think about their future identities? Their answer points to a central conclusion of this volume: Pacific Islanders have been migrating for a long time, although for a variety reasons rather than just because of environmental damage, and Pacific diasporas already exist. These transnational networks suggest themselves as a "useful entry point" (198) for starting to think about an anthropology of climate migration that does not assume an overly static, essentialized concept of place and belonging. At the same time, Kempf and Hermann also remind us that attachment to place is enhanced by its vulnerability: I-Kiribati worry about the loss of the graves of their ancestors by way of expressing the prospect of the tragedy of place-loss. Some refuse to leave, while others give up and go take up a life of multiple belonging.

The editorial construction of this collection is uneven, as I suggested above. Its authors make little or no effort to interact either with the introductory chapter or with each other and I have expressed reservations about the epilogue. On the whole, however, Belonging in Oceania remains a fascinating volume, one that will intrigue regional scholars or anyone else interested in diasporas in this increasingly globalized world or who is influenced by the "mobility turn" in contemporary social theory. Perhaps it could also be usefully included in courses on the contemporary Pacific or on the moral challenges posed by the conflicting pressures of transnational loyalties.

David Lipset is professor of anthropology at the University of Minnesota. He has done fieldwork on masculinity, culture, and modernity among the Murik Lakes people of Papua New Guinea since 1981. He is the author of two books: Gregory Bateson: The Legacy of a Scientist (1982), and Mangrove Man: Dialogics of Culture in the Sepik Estuary (1997). He has co-edited two books and has written many journal articles. The author may be contacted at lipseoo1@umn.edu.

\section{Note}

1 See Marc Augé, Non-Places: An Introduction to Supermodernity, trans. John Howe (New York: Verso, 1995); James Clifford, Routes: Travel and Translation in the Late Twentieth Century (Cambridge, MA: Harvard University Press, 1997); David Lipset and Richard Handler, Vehicles: Cars, Canoes and Other Metaphors of Moral Imagination (New York: Berghahn, 2014); Cathy A. Small, Voyages: From Tongan Villages to American Suburbs (Ithaca, NY: Cornell University Press, 1997); and John Urry, Sociology beyond Societies: Mobilities for the Twenty-First Century (London: Routledge, 2000).
(C) Author(s), 2015. This open-access work is licensed under a Creative Commons Attribution-NonCommercial 4.0 International licence.
Cette oeuvre en libre accès fait l'object d'une licence Creative Commons Attribution-NonCommercial 4.0 International. 